\title{
A SYSTEMATIC LITERATURE REVIEW ON STOCHASTIC PROGRAMMING MODELS IN THE RETAIL INDUSTRY
}

\author{
C. Bisset ${ }^{1} \&$ S.E. Terblanche ${ }^{1 *}$
}

\section{ARTICLE INFO}

\section{Article details}

Presented at the $32^{\text {nd }}$ annual conference of the Southern African Institute for Industrial Engineering (SAllE), held from 4-6 October 2021 in Muldersdrift, South Africa.

Available online

29 Nov 2021

Contact details

Corresponding author

Fanie.Terblanche@nwu.ac.za

\section{Author affiliations}

1 School of Industrial Engineering, North-West University, South Africa

\section{ORCID® identifiers}

C. Bisset

https://orcid.org/0000-0001-5296-5945

S.E. Terblanche

https://orcid.org/0000-0001-9467-9197

DOI

http://dx.doi.org/10.7166/32-3-2611

\section{ABSTRACT}

Optimisation under uncertainty, also referred to as stochastic optimisation, originated during the 1950s. This research field was later extended into prominent application areas, including finance, energy, and production planning. During the 1970s, stochastic programming was first applied in the marketing industry. Interest in this field grew exponentially during the early 2000s, and was identified as one of the most promising future research fields for optimisation. Stochastic programming is an asset for the following world researchers due to its uncertainty calculation. This paper aims to identify and evaluate all existing stochastic programming models in the literature in the retail industry. First, a historical overview of marketing models is provided, with a specific focus on stochastic optimisation. Second, all stochastic programming model applications in the retail industry are identified by conducting a systematic literature review. Last, potential gaps for future research opportunities are identified to help retailers to improve their marketing strategies.

\section{OPSOMMING}

Optimering te midde van onsekerheid, ook bekend as stogastiese optimering, het in die 1950's ontstaan. Hierdie navorsingsveld is later uitgebrei tot noemenswaardige toepassingsareas, soos finansies, energie en produksiebeplanning. Stogastiese programmering is in die 1970's vir die eerste keer in die bemarkingsbedryf toegepas. Belangstelling in die veld het eksponensieel gegroei in die vroeë 2000's en dit is as een van die mees belowende navorsingsvelde van die toekoms identifiseer. Stogastiese programmering is 'n bate vir toekomstige navorsers omdat dit onsekerheid bereken. Hierdie artikel poog om die bestaande stogastiese programmeringsmodelle in die literatuur relevant tot die kleinhandelbedryf te identifiseer en te evalueer. Eerstens word 'n geskiedkundige oorsig verskaf. Daarna word die toepassings van stogastiese programmering in die kleinhandelbedryf identifiseer deur middel van 'n sistematiese literatuurstudie. Laastens word moontlike gapings vir toekomstige navorsingsgeleenthede identifiseer om kleinhandelaars by te staan om hul bemarkingstrategieë te verbeter.

Before the 1960s, marketing decisions were mainly based on the decision-maker's experience and judgement [1]. For this reason, analytical and mathematical models were developed during the first half of $1960[2,3]$. These studies contain different content about how analysts could effectively use the existing mathematical models in marketing, media planning, and pricing. These analytical models were developed to improve the marketing of a product and customer relationship management (CRM). CRM systems were integrated with these analytical models to eliminate mass-marketing and enable one-to-one marketing.

CRM is a systematic approach that provides insight into customers' behaviours and personal characteristics. The concept of mass marketing was first developed during the Industrial Revolution (IR). With mass marketing, the primary purpose is to reach more customers and to expand the customer foundation by focusing on marketing a product. However, researchers indicated that a high cost was linked to acquiring new customers with mass marketing [4]. Thus firms replaced the old model and its product-orientated view 
with a new model - a customer-oriented view. Analysing a customer's behaviour and personal characteristics enables one-to-one marketing and eliminates the need for mass marketing. The purpose of one-to-one marketing is to focus on customer needs, build current customer relationships, and shift away from the breadth of the customer base.

In what follows, a historical overview of the development of marketing models is discussed, followed by a detailed explanation of stochastic optimisation.

\subsection{A historical overview of the development of marketing models}

\subsubsection{The beginning (1960 - 1969)}

The theorem of marketing mix optimisation was first discovered in 1954 [5]. The application of operation research techniques originated from these discoveries and publications, including linear programming and goal programming $[6,7]$.

\subsubsection{The golden decade (1970 - 1979)}

The 1970s were referred to as the golden decade for the development of marketing models. The marketing industry grew exponentially and, as various authors indicate, gained its own identity [1]. Several approaches were discovered and applied during this decade, such as stochastic models [8], response models [9], and labelled marketing-decision models [10].

\subsubsection{Towards generalisations and marketing knowledge (1980 - 1989)}

The purpose of generalisation is to summarise the existing knowledge of a subject or research area. The meta-analyses for several marketing instruments were discovered and applied in marketing [11]. A critical discovery during the late 1980s was that artificial intelligence (AI) techniques could be used to store marketing knowledge in computers. As a result, expert systems and knowledge-based systems were developed and applied to assist with decision-making processes [12].

\subsubsection{The marketing information revolution (1990 - 1999)}

During the 1990s, essential customer data became available, including point-of-purchase scanner data. The development of new marketing models enhanced the field of sales promotions. New models were introduced for sales promotions, such as consumer choice models [13]. Researchers found data-mining techniques during this decade owing to increased data availability. The development of direct marketing models grew tremendously from the 1990s to the early 2000s. The approach referred to as 'theoretical modelling' was discovered in the 1990s, in which a marketing phenomenon is described using different mathematical equations based on assumptions [14].

\subsubsection{The customer-centric approach (2000 - present)}

During the early 2000s, CRM systems and models were developed to ensure that a customer-centric approach was followed - i.e., models for predicting churn and models that target customers for marketing campaigns. The main focus was on individual customers and their specific needs. Customer-relationship models and customer life-time value (CLV) models were developed during this decade $[15,16]$.

From this historical overview, the evolution of marketing models can be seen. It is apparent that, as the technology improved, so did the development of marketing models. Decisions were first based on judgement and experience. As time advanced, decisions were made by analytical models that are based on scientific evidence.

Marketing models can be divided into diverse fields and applications, as seen in Section 1.1. One essential field that was explored during the 1970s was stochastic optimisation. Stochastic optimisation is an asset for the following world researchers due to its uncertainty prediction, which has been skipped in deterministic experiments globally [17]. As discussed, there is an uncertainty associated with customer behaviour and purchasing patterns. Stochastic optimisation enables the decision-maker to be more adequately equipped and prepared to face uncertainty in the future than with deterministic optimisation. For this reason, stochastic optimisation models are explored further in Section 1.2.

\subsection{Optimisation under uncertainty}

Stochastic optimisation was introduced during the late 1950s, and is also referred to as 'optimisation under uncertainty'. Stochastic optimisation's counterpart, deterministic optimisation, is where the outcome and data are known before the decision is made. It is difficult to find examples of systems to analyse that do not include randomness or uncertainty. Stochastic optimisation is a sufficient representation of real-life scenarios in which any decision outcome is uncertain [8]. Therefore, stochastic optimisation adds meaningful value to industries, and is applied in finance, scheduling, and energy. Stochastic optimisation 
is divided into three categories: chance-constrained programming (CCP), robust optimisation (RO), and stochastic programming (SP). The main focus of this study is on stochastic programming and chanceconstrained programming; it excludes robust optimisation. Stochastic programming is an extension of linear or non-linear models to decision models under uncertainty, where the random parameters are represented as a probability distribution [8]. Hellemo et al. [19] provided a detailed outline of stochastic programming models with recourse. These models consider two types of uncertainty: exogenous uncertainty and endogenous uncertainty. A detailed overview is provided in Section 1.2.1).

\subsubsection{Stochastic models with recourse}

Stochastic problems with recourse seek to allocate an optimal number of resources to an activity to maximise a profit or to minimise costs. The number of resources allocated can be treated as an integer variable or as a continuous variable [18]. Exogenous uncertainty is not decision-dependent, meaning that the random probability distribution is not dependent on any decision in the model [19]. These probabilities are generated from historical data, and the model seeks the solution that will do best in meeting expectations.

Endogenous uncertainty problems are decision-dependent, meaning that the decision made at one point in time will influence the uncertain parameters in the future [19]. The uncertainty of parameters includes the availability of information or the probabilities of a realisation. Endogenous uncertainty is addressed by formulating a two-stage stochastic programming model or a multi-stage stochastic programming model.

\section{A two-stage programming model}

A two-stage stochastic model considers two decisions that are made at two different stages. The first decision is made at the first stage, and the second at the second stage. It is critical to note that the firststage decision is mainly based on judgement and experience. The second-stage decision is based on the realisations of the stochastic parameters [20]. Consider the example of a manufacturer outlined by Shapiro et al. [20].

A manufacturer needs to produce $(n)$ products based on customer demand $D=\left(D_{1}, \ldots, D_{n}\right)$, modelled as a random vector. The manufacturer first needs to order parts at the beginning of the planning horizon from a third-party supplier. There is a total of $(m)$ different parts. Each product $(i)$ requires a specific number of units per part $(j)$. This parameter is formulated as $\left(a_{i j}\right)$, where $(i=1, \ldots, n)$ and $(j=1, \ldots, m)$. The manufacturer does not know the customer demand when they order parts. The parts are ordered with a cost per unit, formulated as $\left(c_{j}\right)$. Once the customer demand is known, the manufacturer can decide which demand to satisfy to minimise the overall costs. It is important to note that this decision is made without exceeding the number of parts ordered during the first stage. The first-stage decision $\left(x_{j}\right)$ represents the number of parts to be ordered. The second-stage decisions $\left(z_{i}\right)$ and $\left(y_{j}\right)$ represent the number of units produced and the number of parts left after production respectively. The variable $\left(l_{i}\right)$ denotes the additional cost of satisfying each unit of demand for a product $(i)$. The selling price for a product is formulated as $\left(q_{i}\right)$. Parts that are not used during production are classified as salvage values $\left(s_{j}<c_{j}\right)$. Once the demand becomes known, the manufacturer has to decide how much of each product to produce. Based on the number of parts ordered during the first stage, the optimal allocation of resources needs to be conducted to minimise the overall costs.

The solutions of the vectors $(z)$ and $(y)$ depend on the realisation of the demand, formulated as a random vector $(D)$. The objective function of the problem can be formulated as follows.

Minimise the overall costs

$$
c^{T} x+\mathbb{E}[Q(x, D)], x \geq 0
$$

The probability distribution of the demand, formulated as a random vector $(D)$, is considered. This objective function's first part $\left(c^{T} x\right)$ represents the ordering cost, and the second part $(\mathbb{E}[Q(x, D)])$ represents the expected cost. The problem is formulated with different demand scenarios $\left(d^{1}, \ldots, d^{K}\right)$, each with a positive probability, represented as $\left(p_{1}, \ldots, p_{K}\right)$. The two-stage problem is formulated as follows.

Minimise

subject to

$$
c^{T} x+\sum_{k=1}^{K} p_{k}\left[(l-q)^{T} z^{k}-s^{T} y^{k}\right]
$$

$$
\begin{gathered}
y^{k}=x-A^{T} z^{k}, k=1, \ldots, K \\
0 \leq z^{k} \leq d^{k}, y^{k} \geq 0, k=1, \ldots K
\end{gathered}
$$




$$
x \geq 0
$$

The objective function (2) minimises the overall cost. The minimisation is performed over all vectors $\left(z^{k}\right),\left(y^{k}\right)$ and $(x),(k=1, \ldots, K)$. The solutions to the vectors $(z)$ and $(y)$ depend on the scenario $(k)$. The demand for each scenario is different; thus the number of variables and constraints is proportional to the number of scenarios $(k)$ in the problem. Equation (3) introduces the matrix $(A)$ with entries $\left(a_{i j}\right)$. The firststage decision $\left(x_{j}\right)$ is made before the demand is known, and is therefore independent of all random variables. The second-stage decisions $\left(z_{i}\right)$ and $\left(y_{j}\right)$ are made after the demand becomes known.

\section{A multi-stage programming model}

A multi-stage stochastic programming model consists of multiple stages and multiple decisions [20]. A decision is made at a stage based on the information available at that moment. Consider the manufacturer example given above for the two-stage model. Assume that all costs and prices are the same in all periods. For a multi-stage problem, the manufacturer has to make production decisions at the successive stages and not at the beginning of the planning horizon. The first-stage decision $\left(x_{t-1}=x_{t-1,1, \ldots .,}, x_{t-1, n}\right)$ represents the number of parts to be ordered at the beginning of stage $(T)$. This decision is made without knowing what the customer demand will be. The second-stage decisions $\left(z_{t}\right)$ and $\left(y_{t}\right)$ represent the number of units produced during a stage $(T)$ and the number of parts left after production at the end of stage $(T)$ respectively. The order quantities in one stage depend on the past demand realisation, denoted as $\left(D_{t-1}\right)$. For this reason, the subscript of $(t-1)$ is used. A multi-stage problem for this example can be formulated as follows.

Minimise

$$
c^{T} x_{0}+\mathbb{E}\left[Q_{1}\left(x_{0}, D_{1}\right)\right], x_{0} \geq 0
$$

The first part of this objective function $\left(c^{T} x_{0}\right)$ represents the ordering cost, and the second part $\left(\mathbb{E}\left[Q_{1}\left(x_{0}, D_{1}\right)\right]\right)$ represents the expected cost. The formulation of the objective function for a multi-stage problem is different from the two-stage problem, since the objective function is not formulated as a computationally accessible form. This objective function is a result of recursive optimisation. The problem at a stage $(t=T-1, \ldots, 1)$ is formulated as follows.

Minimise

subject to

$$
(l-q)^{T} z_{t}+h^{T} y_{t}+c^{T} x_{t}+Q_{t+1}\left(x_{t}, y_{t}, d_{[t]}\right)
$$

with

$$
\begin{gathered}
y_{t}=y_{t-1}+x_{t-1}-A^{T} z_{t} \\
0 \leq z_{t} \leq d_{t}, y_{t} \geq 0
\end{gathered}
$$

$$
Q_{t+1}\left(x_{t}, y_{t}, d_{[t]}\right):=\mathbb{E}\left\{Q_{t+1}\left(x_{t}, y_{t}, D_{[t+1]}\right) \mid D_{[t]}=d_{[t]}\right\}
$$

An optimal value is obtained by $\left(Q_{t}\left(x_{t-1}, y_{t-1}, d_{[t]}\right)\right)$. The variable $\left(y_{0}\right)$ represents the inventory levels at each stage. The optimal value function $\left(Q_{1}\left(x_{o}, D_{1}\right)\right)$ in the problem depends on the initial order $\left(x_{0}\right)$ and the realisation of the demand $\left(d_{1}\right)$.

\subsection{Chance-constrained problems}

Chance-constrained problems are concerned with managing or mitigating the risk with decision-making under uncertainty [20]. The manufacturer does not want to risk losing customers if a wrong decision is made during the first stage. Therefore, the manufacturer must ensure that the probability of satisfying all demand $\left(D=\left(D_{1}, \ldots, D_{n}\right)\right)$, is more significant than a specific value, also referred to as a fixed service level $(1-\alpha)[20]$. The set $\left(D_{\alpha}\right)$ is formulated and known as the uncertainty set. The chance-constrained problem is formulated as follows.
Minimise
subject to

$$
c^{T} x, x \geq 0
$$

$$
A^{T} d \leq x, \forall d \in D_{\alpha}
$$

It is important to note that $\left(x_{j}\right)$ denotes the minimum number of units required to satisfy every demand $\left(d \epsilon D_{\alpha}\right)$. 
Therefore,

$$
x_{j}=\max \sum_{i=1}^{n} a_{i j} d_{i}, \forall d \epsilon D_{\alpha}, j=1, \ldots, n
$$

This is to ensure that the problem's solution is independent of the cost $\left(c_{j}\right)$ and depends on the uncertainty set $\left(D_{\alpha}\right)$.

Statistical problems exist that are also related to stochastic programmes. There is a difference between the formulation of statistical stochastic problems and decision-making under uncertainty [20]. In mathematical statistics, the focus is on the analysis of 'wait-and-see' solutions. In engineering, decisionmaking under uncertainty is mainly concerned with the 'here-and-now' decisions, where the random variables are considered to make optimal decisions at that very moment.

Retailers need to develop marketing models to assist them with making accurate 'here-and-now' decisions. Critical data, such as future customer demands, are not always available, leading to unexpected events, including a loss in profit or customer dissatisfaction. Stochastic programming models will assist retailers to prevent these wrong decisions from being made, and they will assist retailers to allocate resources to maximise profitability.

An overview of the history of marketing models and stochastic optimisation is provided in Sections 1.1 to 1.3. A systematic literature review (SLR) is conducted in Section 2 to identify the existing stochastic programming models in the literature. Last, Section 3 identifies potential future research opportunities. All three steps are linked to demonstrate where marketing models have come from, how they are currently used, and how they could be developed further to assist retailers to optimise their future marketing strategies.

\section{A SYSTEMATIC LITERATURE REVIEW: IDENTIFYING THE EXISTING STOCHASTIC MARKETING MODELS IN THE LITERATURE}

\subsection{Research method and research results}

The systematic literature review, also referred to as research synthesis, originated in the medical industry. Medical experts' opinions and advice are not considered to be as reliable as opinions and advice based on scientific experiments [21]. It is important to note that a systematic literature review does not create new knowledge. Rather, this type of review seeks to summarise all existing knowledge based on a specific topic. Therefore, this study is classified as a secondary-research study. The systematic literature review conducted in this study followed the guidelines outlined and proposed by Kitchenham et al. [22] and Kitchenham [23]. A review protocol is thus developed, as depicted in Figure 1. This protocol specifies the eligibility of studies that must be included, and it also presents all the methods that are needed to conduct this review [21]. Four research questions were formulated to identify and evaluate the current studies in the literature effectively. First, the number of studies over the five years was identified. Second, the type of stochastic optimisation approaches applied in these studies was identified. Third, the type of uncertainty was evaluated, followed by the possible future research opportunities identified in the marketing campaign category.

A search process was applied in which keywords were identified, followed by the seven particular databases that were used in the search: Google Scholar, Science Direct, Scopus, IEEE, Web of Science, EBSC Host, and Emerald Insight. Inclusion criteria and exclusion criteria were created in conjunction with quality assessment criteria. These phases were applied to ensure that all relevant studies were included in this review. The studies were captured according to several characteristics.

It is important to note that the search was conducted for the period from 2016 to 2021 . The primary purpose of conducting a systematic literature review was to identify the current stochastic optimisation models in the literature. A detailed overview of these studies is given and discussed in Table 1. 


\section{Research Questions}

\begin{tabular}{|l|l|l|l|}
\hline Research Question 1 & Research Question2 & Research Question3 & Research Question 4 \\
\hline $\begin{array}{l}\text { How many studies } \\
\text { that applied } \\
\text { stochastic } \\
\text { optimisation } \\
\text { approaches were } \\
\text { published during the } \\
\text { year ranges (2016- } \\
\text { 2021)? }\end{array}$ & $\begin{array}{l}\text { What types of } \\
\text { stochastic } \\
\text { optimisation approach } \\
\text { are applied in the } \\
\text { existing literature? }\end{array}$ & $\begin{array}{l}\text { What types of } \\
\text { uncertainty do the } \\
\text { stochastic problems } \\
\text { with recourse } \\
\text { consider in the } \\
\text { literature? }\end{array}$ & $\begin{array}{l}\text { What are the possible } \\
\text { future research } \\
\text { opportunities } \\
\text { identified in the } \\
\text { studies in the } \\
\text { marketing campaign } \\
\text { category? }\end{array}$ \\
\hline
\end{tabular}

\section{Search Process}

\begin{tabular}{|c|c|}
\hline Keywords & Databases \\
\hline $\begin{array}{l}\text { - "Stochastic optimisation" AND "advertising } \\
\text { budget" OR "Stochastic optimization" AND } \\
\text { "advertisingbudget". }\end{array}$ & $\begin{array}{l}\text { : Google Scholar } \\
\text { Science Direct } \\
: \text { Scopus } \\
\text { IEEE } \\
: \text { Web of Science } \\
\text { EBSC Host (Academic search premier, E- } \\
\text { Journals, MathSciNet) } \\
\text { Emerald Insight }\end{array}$ \\
\hline
\end{tabular}

\section{Inclusion and Exclusion criteria}

\begin{tabular}{|c|c|}
\hline Inclusion Criteria & Exclusion Criteria \\
\hline $\begin{array}{l}\text { - Studies with the following keywords: } \\
\text { "Stochastic optimisation" AND } \\
\text { "advertising budget" OR "Stochastic } \\
\text { optimization" AND "advertising budget". }\end{array}$ & $\begin{array}{l}\text { Non-English literature } \\
\text { - Non-retail applications } \\
\text { Stochastic optimisation referring to } \\
\text { statisticallearning and not decision-making } \\
\text { under uncertainty }\end{array}$ \\
\hline
\end{tabular}

\section{Quality Assessment}

\begin{tabular}{|l|l|l|l|}
\hline Phase 1 & Phase 2 & Phase 3 & Phase 4 \\
\hline $\begin{array}{l}\text { Identify all studies } \\
\text { with the allocated } \\
\text { keywords. The } \\
\text { keywords were used } \\
\text { to identify the } \\
\text { studies. Both the UK } \\
\text { and US spelling were } \\
\text { used to ensure that } \\
\text { all studies were } \\
\text { identified. }\end{array}$ & Remove all duplicates & $\begin{array}{l}\text { Identify studies that } \\
\text { applied a stochastic } \\
\text { programming } \\
\text { approach within the } \\
\text { retail industry. }\end{array}$ & $\begin{array}{l}\text { Identify studies that } \\
\text { included an allocated } \\
\text { advertising budget }\end{array}$ \\
\hline
\end{tabular}

\section{Data collection and Data analysis}

\begin{tabular}{|c|c|}
\hline Data Collection & Data Analysis \\
\hline $\begin{array}{l}\text { 1. Research Title } \\
\text { 2. The applicable year of publication. All } \\
\text { 3. Knowies that were published since } 2016 . \\
\text { 4. Summary of the study } \\
\text { 5. The approach followed in the study } \\
\text { 6. Author(s) and reference }\end{array}$ & 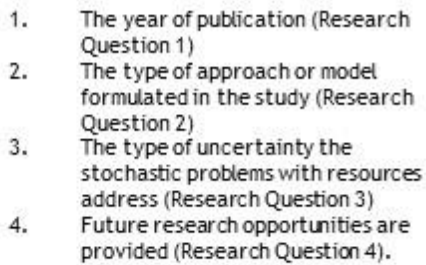 \\
\hline
\end{tabular}

$\underline{\text { Research Results }}$

\begin{tabular}{|c|c|}
\hline Phase and description & Results \\
\hline $\begin{array}{l}\text { Phase 1: Identify studies with the following } \\
\text { keywords: "Stochastic optimisation" AND } \\
\text { "advertising budget" OR "Stochastic } \\
\text { optimization" AND "advertising budget". }\end{array}$ & $\begin{array}{ll}\text { : } & \text { Google Scholar - } 40 \\
\text { Science Direct - } 6 \\
\text { Scopus - } 10 \\
\text { IEEE-1 } \\
\text { Web of Science - } 10 \\
\text { EBSC Host (Academic search } \\
\text { premier, E-Journals, MathSciNet) - } 2 \\
\text { Emerald Insight - 2 } \\
\end{array}$ \\
\hline Phase 2: Remove all duplicates & $\begin{array}{ll}: & \text { Google Scholar - 40 } \\
\text { Science Direct - } 1 \\
\text { Scopus - } 4 \\
\text { IEEE - } 0 \\
\text { Web of Science - 10 } \\
\text { EBSC Host (Academic search } \\
\text { premier, E-Journals, MathSciNet) - } 1 \\
\text { Emerald Insight - } 1\end{array}$ \\
\hline $\begin{array}{l}\text { Phase } 3 \text { : Identify studies that applied a } \\
\text { stochastic programming approach within the } \\
\text { retail industry }\end{array}$ & $\begin{array}{ll}: & \text { Google Scholar - } 9 \\
\text { Science Direct - 0 } \\
\text { Scopus - 0 } \\
\text { IEEE-0 } \\
\text { Web of Science - 1 } \\
\text { EBSC Host (Academic search } \\
\text { premier, E-Journals, MathSciNet) - } 0 \\
\text { Emerald Insight - } 0\end{array}$ \\
\hline $\begin{array}{l}\text { Phase 4: Identify studies that included an } \\
\text { allocated advertising budget }\end{array}$ & $\begin{array}{ll}: & \text { Google Scholar - } 8 \\
\text { Science Direct - } 0 \\
\text { Scopus - 0 } \\
\text { IEEE - } 0 \\
\text { Web of Science-1 } \\
\text { EBSC Host (Academic search } \\
\text { premier, E-Journals, MathSciNet) - } 0 \\
\text { Emerald Insight - } 0\end{array}$ \\
\hline
\end{tabular}

Figure 1: A demonstration of the research protocol and the research results 
Table 1: Results of the systematic literature review

\begin{tabular}{|c|c|c|c|c|c|c|}
\hline No. & Study title & Year & Knowledge area & Summary & Approach/Model & Author(s) \& Ref \\
\hline 1 & $\begin{array}{l}\text { Optimal } \\
\text { keywords } \\
\text { grouping in } \\
\text { sponsored } \\
\text { search } \\
\text { advertising } \\
\text { under uncertain } \\
\text { environments }\end{array}$ & 2020 & $\begin{array}{l}\text { Search } \\
\text { advertising }\end{array}$ & $\begin{array}{l}\text { This study provides valuable managerial insights for advertisers, } \\
\text { and will assist them with their decision-making process. A single- } \\
\text { stage stochastic programming model has been formulated to deal } \\
\text { with uncertainty in search advertising decisions. The random } \\
\text { variable in the model is the click-through rate (CTR). The model } \\
\text { considers various constraints, including a budget and an } \\
\text { advertiser's risk tolerance. A branch-and-bound method is } \\
\text { applied to solve the model. }\end{array}$ & $\begin{array}{l}\text { A stochastic problem } \\
\text { with resources }\end{array}$ & Li and Yang [24] \\
\hline 2 & $\begin{array}{l}\text { Combating lead- } \\
\text { time uncertainty } \\
\text { in global supply } \\
\text { chain's } \\
\text { shipment- } \\
\text { assignment: Is it } \\
\text { wise to be risk- } \\
\text { averse? }\end{array}$ & 2020 & $\begin{array}{l}\text { Supply chain } \\
\text { management }\end{array}$ & $\begin{array}{l}\text { This study provides a reliable operational solution by introducing } \\
\text { a risk-hedging policy for shipment assignments. There is } \\
\text { uncertainty with global supply chains regarding the shipping of } \\
\text { goods. A stochastic optimisation model is formulated that } \\
\text { minimises the cost and the value-at-risk to address this } \\
\text { uncertainty. Linearisation techniques are applied to solve this } \\
\text { model. }\end{array}$ & $\begin{array}{l}\text { A chance-constrained } \\
\text { problem (CCP) }\end{array}$ & Sun et al. [25] \\
\hline 3 & $\begin{array}{l}\text { Sponsored } \\
\text { search } \\
\text { advertising and } \\
\text { dynamic pricing } \\
\text { for perishable } \\
\text { products under } \\
\text { inventory-linked } \\
\text { customer } \\
\text { willingness to } \\
\text { pay }\end{array}$ & 2019 & $\begin{array}{l}\text { Search } \\
\text { advertising }\end{array}$ & $\begin{array}{l}\text { This study provides a decision-support model that will assist } \\
\text { retailers with strategic bid and pricing decisions. Retailers } \\
\text { provide inventory availability information on their web pages to } \\
\text { increase customer traffic to the allocated sites. A stochastic } \\
\text { dynamic programming model is formulated to assist retailers with } \\
\text { this decision-making process. } \\
\text { Two variations are developed: } \\
\text { 1. A bidding model - The retailer uses the bid as a } \\
\text { decision variable. The bid is used to increase the respective } \\
\text { sales. } \\
\text { 2. Bid-and-price model - The retailer adjusts the bid and } \\
\text { the price at the beginning of each period. }\end{array}$ & $\begin{array}{l}\text { A stochastic problem } \\
\text { with resources }\end{array}$ & Tunuguntla et al. [26] \\
\hline 4 & $\begin{array}{l}\text { An optimisation- } \\
\text { simulation } \\
\text { approach to } \\
\text { chance- } \\
\text { constraint } \\
\text { programming }\end{array}$ & 2018 & $\begin{array}{l}\text { Marketing } \\
\text { campaign }\end{array}$ & $\begin{array}{l}\text { A stochastic programming model is formulated to generate the } \\
\text { optimal number of advertisements to be placed in various } \\
\text { newspapers. An iterative simulation approach is followed to solve } \\
\text { this problem while various heuristics are considered. A small } \\
\text { number of iterations is generated in this study to ensure that } \\
\text { valuable insight is provided to retailers. A simulation-based } \\
\text { approach is introduced to discover the probabilities that will } \\
\text { most likely satisfy the chance constraints. }\end{array}$ & $\begin{array}{l}\text { A chance-constrained } \\
\text { problem }(C C P) .\end{array}$ & Marković et al. [27] \\
\hline
\end{tabular}




\begin{tabular}{|c|c|c|c|c|c|c|}
\hline No. & Study title & Year & Knowledge area & Summary & Approach/Model & Author(s) \& Ref \\
\hline 5 & $\begin{array}{l}\text { Marketing } \\
\text { optimisation } \\
\text { methods }\end{array}$ & 2016 & $\begin{array}{l}\text { Marketing } \\
\text { campaign }\end{array}$ & $\begin{array}{l}\text { This study provides valuable insight into macro-marketing } \\
\text { optimisation models. The main focus is on models that were } \\
\text { formulated during the last } 20 \text { years. Future research } \\
\text { opportunities are identified and discussed accordingly. The } \\
\text { authors introduce ways for an analyst to formulate and solve } \\
\text { various contemporary marketing problems. This chapter serves as } \\
\text { a guideline for analysts by identifying the optimum instruments } \\
\text { to maximise firm and customer-level outcomes. Predictive } \\
\text { models, response functions, different solving techniques, and } \\
\text { objective functions are discussed in this study. This study does } \\
\text { not approach a specific problem, but can be used for guidance. }\end{array}$ & Other & $\begin{array}{l}\text { Mantrale and Kanuri } \\
\text { [28] }\end{array}$ \\
\hline 6 & $\begin{array}{l}\text { Multicriteria and } \\
\text { robust extension } \\
\text { of news-boy } \\
\text { problems }\end{array}$ & 2018 & $\begin{array}{l}\text { Supply chain } \\
\text { with a specific } \\
\text { focus on } \\
\text { inventory }\end{array}$ & $\begin{array}{l}\text { A newsvendor problem is solved in a single-period stochastic } \\
\text { optimisation framework. The demand is identified as the random } \\
\text { parameter in this study. The simple model is extended by } \\
\text { applying different techniques and functions. The sample average } \\
\text { approximation (SAA) technique is applied and is generated from } \\
\text { accurate data. The author applies the SAA method to solve these } \\
\text { models. Since the model only considers the newsvendor's recent } \\
\text { decision, this model is a single-stage stochastic optimisation } \\
\text { problem. } \\
\text { 1. The objective value consists of the following: } \\
\text { 2. Conditional value at risk (CVaR) and an expected function. } \\
\text { 3. Multicriteria with price-dependent demand } \\
\text { 4. Multiproduct with dependent and independent demands } \\
\text { 5. Distributional robustness }\end{array}$ & $\begin{array}{l}\text { A stochastic problem } \\
\text { with resources }\end{array}$ & Sedina [29] \\
\hline 7 & $\begin{array}{l}\text { Multiperiod } \\
\text { multiproduct } \\
\text { advertising } \\
\text { budgeting: } \\
\text { Stochastic } \\
\text { optimisation } \\
\text { modelling }\end{array}$ & 2016 & $\begin{array}{l}\text { Marketing } \\
\text { campaign }\end{array}$ & $\begin{array}{l}\text { This study provides retailers with valuable managerial insight for } \\
\text { an advertising campaign. A stochastic optimisation model is } \\
\text { formulated for a multiproduct, multiperiod advertising budgeting } \\
\text { problem. A deterministic version is also formulated, and the } \\
\text { results are compared. The authors develop a single-stage } \\
\text { stochastic optimisation model with a deterministic feasible set of } \\
\text { data. The main objective is to maximise the profit of sales as a } \\
\text { result of advertising. This study generates the optimal } \\
\text { multiproduct advertising budget for a planning horizon and how } \\
\text { to allocate it during the periods. The study also provides insight } \\
\text { into stochastic and deterministic models by comparing the } \\
\text { allocated results. }\end{array}$ & $\begin{array}{l}\text { A stochastic problem } \\
\text { with resources }\end{array}$ & Beltran-Royo et al. \\
\hline
\end{tabular}




\begin{tabular}{|c|c|c|c|c|c|c|}
\hline No. & Study title & Year & Knowledge area & Summary & Approach/Model & Author(s) \& Ref \\
\hline 8 & $\begin{array}{l}\text { On the multi- } \\
\text { stage influence } \\
\text { maximisation } \\
\text { problem }\end{array}$ & 2016 & $\begin{array}{l}\text { Search } \\
\text { advertising }\end{array}$ & $\begin{array}{l}\text { This study develops a model that maximises the effect of } \\
\text { influences on social networks. One decision made by one } \\
\text { participant can influence another's decision. The study aims to } \\
\text { maximise these influences by proposing a multi-stage version of } \\
\text { the problem. The problem is solved by applying greedy and } \\
\text { particle swarm optimisation algorithms. The model has two } \\
\text { significant decisions: the first is to whom impressions should be } \\
\text { allocated, and the second is in which stage. It is important to } \\
\text { note that the problem should be resolved in each stage, since } \\
\text { the previous stage's outcomes should be considered. }\end{array}$ & $\begin{array}{l}\text { A stochastic problem } \\
\text { with resources }\end{array}$ & $\begin{array}{l}\text { Rahaman and Hosein } \\
\text { [31] }\end{array}$ \\
\hline 9 & $\begin{array}{l}\text { A stochastic } \\
\text { algorithm for } \\
\text { online bipartite } \\
\text { resource } \\
\text { allocation } \\
\text { problems }\end{array}$ & 2016 & $\begin{array}{l}\text { Search } \\
\text { advertising }\end{array}$ & $\begin{array}{l}\text { The authors formulate a stochastic model to solve a resource } \\
\text { allocation problem. Consumers have a limited budget, and want } \\
\text { to purchase items that become available one at a time. The } \\
\text { model allocates items to potential buyers in an online setting to } \\
\text { maximise the total revenue. Single-stage and multi-stage } \\
\text { stochastic optimisation models are formulated. The L-shaped } \\
\text { method is applied to solve this problem. }\end{array}$ & $\begin{array}{l}\text { A stochastic problem } \\
\text { with resources }\end{array}$ & Legrain and Jaillet [32] \\
\hline
\end{tabular}




\subsection{Discussion of results}

\subsubsection{Research question 1: How many studies that applied stochastic optimisation approaches were published during the year ranges (2016-2021)?}

Figure 2 shows a total of nine studies in the literature. Four studies were published in 2016, two in 2018, one in 2019, and two in 2020.

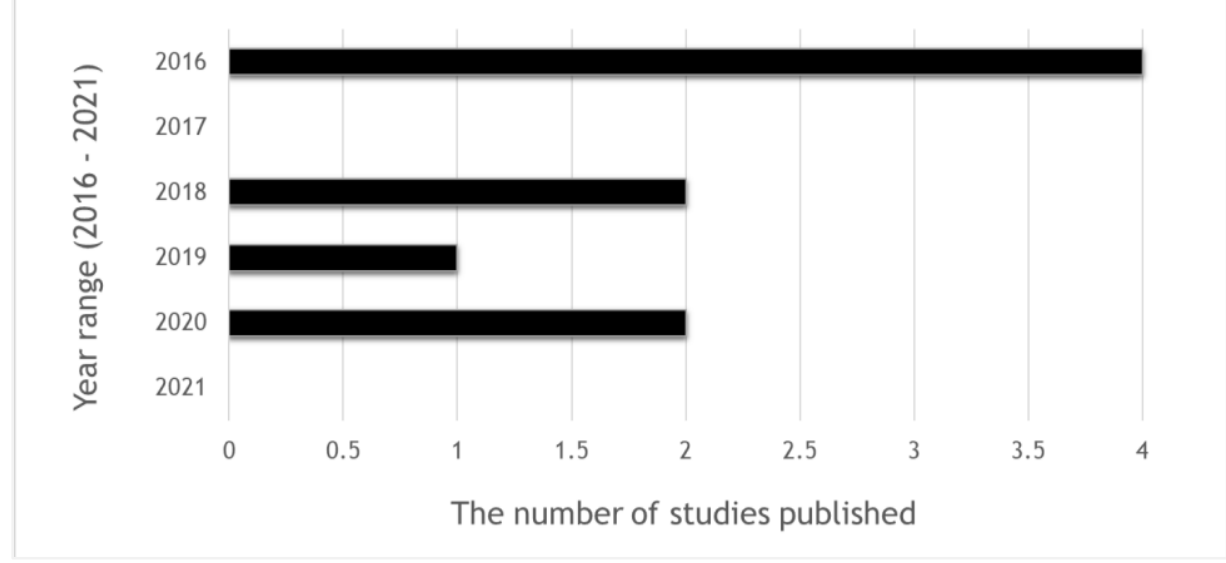

Figure 2: Number of studies published, 2016-2021

\subsubsection{Research Question 2: What types of stochastic optimisation approach are applied in the existing literature?}

The scope of this study has two sections: chance-constrained programming and stochastic programming (recourse problems). The studies are identified according to these sections. The results are shown in Figure 3.

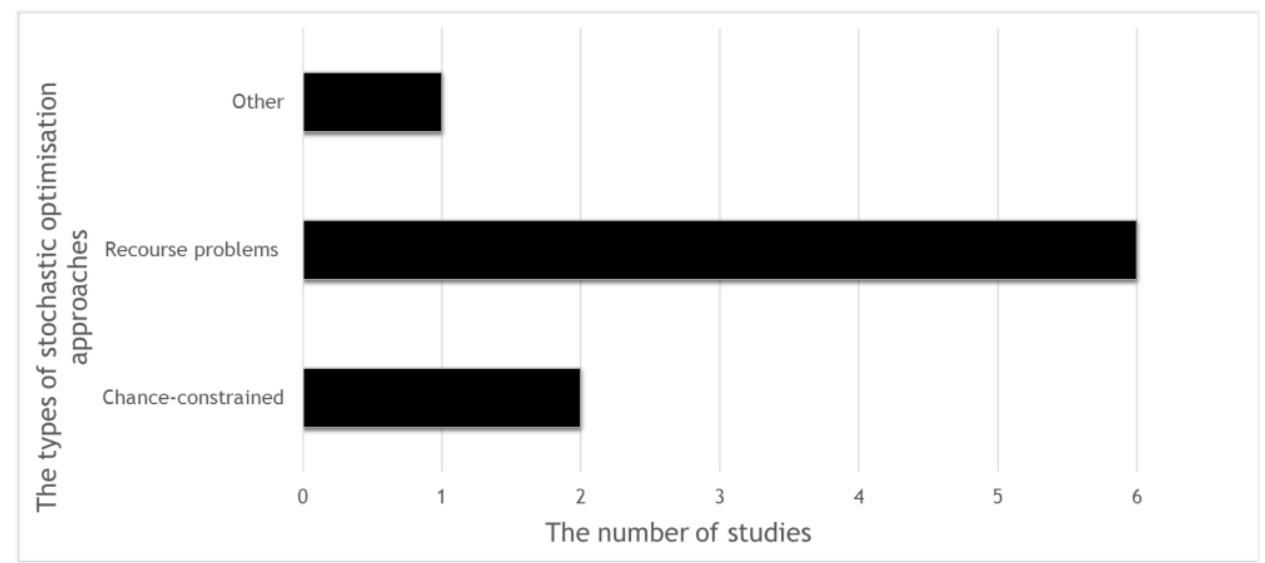

Figure 3: The number of stochastic optimisation studies published in each section

From Figure 3, it is evident that two studies were published that considered chance-constrained problems, and that six studies were published that considered stochastic problems with recourse. Study 5 was classified as 'other'. Therefore, study 5 is classified as a guideline for marketing analysts, and does not focus on one section. Study 5 considers both and provides valuable insight into how to formulate mathematical models to solve the challenges experienced by marketing analysts.

\subsubsection{Research question 3: What types of uncertainty do the stochastic problems with recourse consider in the literature?}

The stochastic programming models developed in these studies are classified as single-stage, two-stage, or multi-stage stochastic programming models. The six studies that consider stochastic problems with recourse are divided into these categories. The results are shown in Figure 4. 


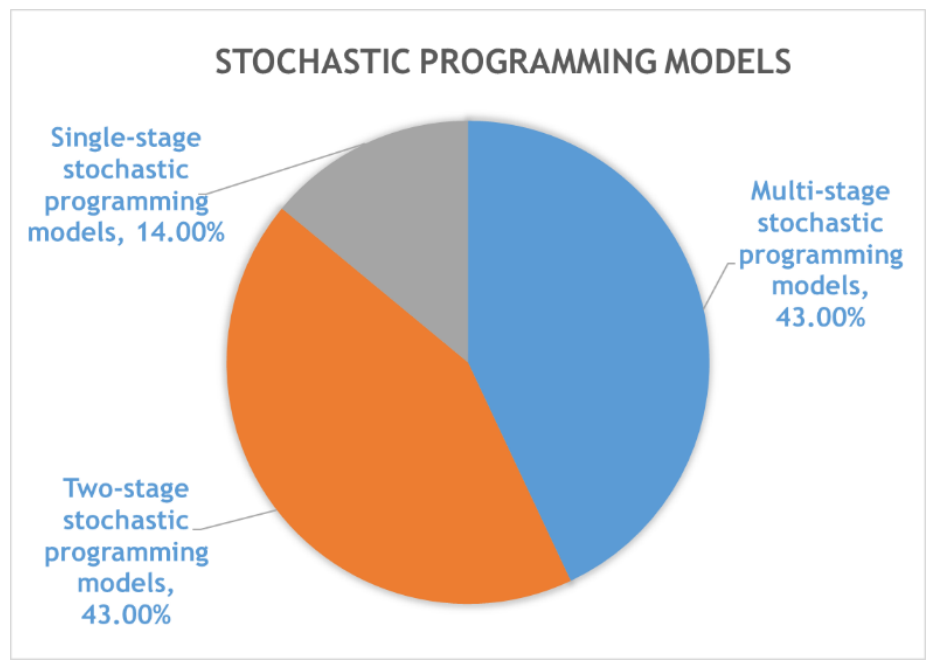

Figure 4: The types of stochastic programming model

From Figure 4, it is clear that 14 per cent of the studies developed single-stage models, 43 per cent developed multi-stage models, and 43 per cent developed two-stage models. The studies identified in the review were evaluated based on the type of uncertainty considered in the study. Study 9 formulated twostage and multi-stage stochastic programming models; so it was added to both categories. In section 1.2 it was shown that two types of uncertainty exist: endogenous uncertainty and exogenous uncertainty. The results are depicted in Table 2.

Table 2: The types of uncertainty

\begin{tabular}{|c|c|}
\hline Type of uncertainty & Study title \\
\hline Endogenous & $\begin{array}{l}\text { 1. } \\
\text { invensored search advertising and dynamic pricing for perishable products under } \\
\text { 2. Multicriteria and robust extension of to pay. } \\
\text { 3. } \\
\text { 4. } \quad \text { An the multi-stage influence maximisation problem. } \\
\text { A stochastic algorithm for online bipartite resource allocation problems. }\end{array}$ \\
\hline Exogenous & $\begin{array}{l}\text { 1. Optimal keywords grouping in sponsored search advertising under uncertain } \\
\text { environments. } \\
\text { 2. Multiperiod multiproduct advertising budgeting: Stochastic optimisation } \\
\text { modelling. }\end{array}$ \\
\hline
\end{tabular}

From the results, it is clear that most of the stochastic programming studies considered endogenous uncertainty.

\subsubsection{Research question 4: What are the possible future research opportunities identified in the studies in the marketing campaign category?}

The knowledge areas are divided into search advertising, supply chain management, and marketing campaigns. Search advertising consists of online advertising via web pages and social networks (ecommerce); supply chain includes operations management and economics; and marketing campaigns include any promotional event implemented in the organisation, including promotions. The six studies identified in Table 2 are divided into the three main categories, as shown in Figure 5. 


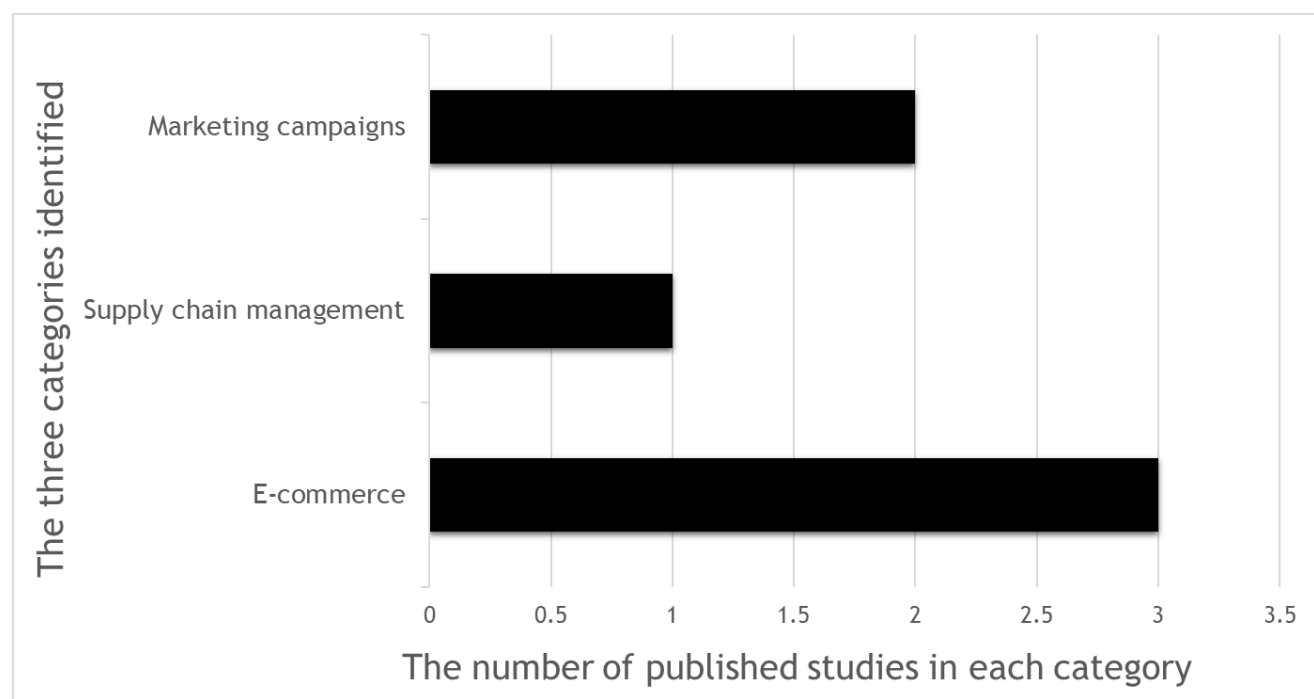

Figure 5: Number of stochastic programming studies published in each category

Figure 5 illustrates three studies in the search advertising category (e-commerce), two in marketing campaigns, and one in supply chain management. To address research question 4 , the two studies identified in the marketing campaign category are discussed in detail.

In study 5 , the authors provided valuable insight into macro-marketing optimisation models. The authors stated that new opportunities exist for marketers to engage with customers and to maximise the probability of a sale, thanks to rapid advances in technology. There are different new opportunities, such as allocating marketing resources at customer touchpoints to maximise profitability and customer lifetime value.

These authors also demonstrated how marketing instruments, including price and promotion, can be used to identify customer behaviour and maximise profitability. Study 7's main objective was to maximise the profit of sales through advertising. A single-stage stochastic optimisation model was formulated alongside a deterministic version of the problem. The stochastic version improved the expected profit by 4.38 per cent. One future research opportunity identified was to improve this model by formulating a two-stage stochastic model that considers stage-based decisions.

\section{CONCLUSION: THE FUTURE OF MARKETING MODELS}

In this study, an overview of the development of marketing models was presented from the early 1960 s to the early 2000s. During the early 2000s, researchers indicated that stochastic optimisation is an asset for subsequent research owing to its ability to consider uncertainty. Uncertainty is linked to customer behaviour and patterns. For this reason, stochastic optimisation was explored further. An overview of stochastic programming models was provided, with a specific focus on two-stage and multi-stage models. An overview of chance-constrained problems was also provided.

The application of stochastic optimisation models was explored further in step 2 by identifying models in the literature from 2016 to 2021 . A research protocol was designed to ensure that the review was conducted effectively and accurately. Four research questions were developed to serve as guidelines when evaluating the search results.

Nine functional research studies were identified, with most of them published in 2016. Six studies were identified that considered stochastic problems with recourse. From these studies, two considered exogenous uncertainty and four considered endogenous uncertainty. It was concluded that most of these studies formulated a two-stage stochastic programming model and a multi-stage stochastic programming model to solve the allocated problems. The six studies were evaluated further by dividing them into three categories: search advertising (e-commerce), supply chain management, and marketing campaigns. Three of these studies were allocated to search advertising, one to supply chain management, and two to marketing campaigns. 
Two studies were identified in the marketing campaign category. The first study provided guidelines to marketers when developing marketing campaign models, and could be used for guidance. The second study was the only one that was identified as applying a stochastic programming model to a marketing campaign case study; however, its main focus was on maximising profit through advertising. Various channels with products were considered in the model. This study had a product-orientated view, and so lacked a customer-orientated perspective. These two studies showed that the literature requires more stochastic programming models that consider a customer-orientated view.

From the results, it is apparent that retailers can improve the implementation of marketing campaigns by focusing on customer behaviour and personal characteristics. Thus implementing CRM systems can enable more one-to-one marketing. Because there is uncertainty in a customer's behaviour, stochastic programming models are formulated to make the best decisions for one-to-one marketing while considering all uncertain behaviour. Several authors indicated that CRM systems and advanced technology, including machine learning and analytical models, would allow retailers to describe customer behaviour accurately and so to predict future sales to maximise profitability from a marketing campaign.

There is a need for more stochastic programming models that consider endogenous uncertainty and which a problem is decision-dependent - meaning that the decision made at one point in time will impact the uncertain parameters in the future. In conjunction with data-mining techniques, stochastic programming models can predict the effect of one-to-one marketing on purchasing patterns. Consider, for example, a targeted customer before a campaign: what is the probability of the customer purchasing that product during the campaign?

With the changes in customer behaviour and uncertainties being experienced in all industries, analytical models must be designed to assist retailers with their future decision-making processes. Decisions cannot be made on the basis of experience and judgement. Therefore, there is a need for more analytical models - specifically, stochastic programming models - in the retailer industry.

\section{REFERENCES}

[1] B. Wierenga and R. Lans, Handbook of marketing decision models. Springer, 2008, vol. 121.

[2] R. D. Buzzell et al., "Mathematical models and marketing management." Mathematical models and marketing management., 1964.

[3] W. Peters, R. Frank, A. Kuehn and W. Massy, "Quantitative techniques in marketing analysis: Text and readings", JMR, Journal of Marketing Research (pre-1986), vol. 1, no. 1, p. 77, 1964.

[4] C. Rygielski, J. Wang and D. Yen, "Data mining techniques for customer relationship management", Technology in Society, vol. 24, no. 4, pp. 483-502, 2002. Available: 10.1016/s0160-791x(02)00038-6.

[5] R. Dorfman and P.O. Steiner, "Optimal advertising and optimal quality", The American Economic Review, vol. 44, no. 5, pp. 826-836, 1954.

[6] J. Engel and M.R. Warshaw, “Allocating advertising dollars by linear programming”, Journal of Advertising Research, vol. 4, pp. 42-48, 1964.

[7] D. B. Montgomery and G. L. Urban, "Management science in marketing," 1969.

[8] L. Marchant, W. Massy, D. Montgomery and D. Morrison, "Stochastic models of buying behaviour", The Statistician, vol. 20 , no. 4, p. 90, 1971. Available: $10.2307 / 2986989$.

[9] D. Clarke, "Econometric measurement of the duration of advertising effect on sales", Journal of Marketing Research, vol. 13, no. 4, p. 345-357, 1976. Available: $10.2307 / 3151017$.

[10] A. Silk and G. Urban, "Pre-test-market evaluation of new packaged goods: A model and measurement methodology", Journal of Marketing Research, vol. 15, no. 2, pp. 171-191, 1978. Available: 10.1177/002224377801500201.

[11] G. Tellis, "The price elasticity of selective demand: A meta-analysis of econometric models of sales", Journal of Marketing Research, vol. 25, no. 4, pp. 331-341, 1988. Available: 10.1177/002224378802500401.

[12] M. Abraham and L. Lodish, "Promoter: An automated promotion evaluation system", Marketing Science, vol. 6, no. 2, pp. 101-123, 1987. Available: $10.1287 / \mathrm{mksc} .6 .2 .101$.

[13] M. Abraham and L. Lodish, "An implemented system for improving promotion productivity using store scanner data”, Marketing Science, vol. 12, no. 3, pp. 248-269, 1993. Available: 10.1287/mksc.12.3.248.

[14] S. Choi, "Price competition in a channel structure with a common retailer", Marketing Science, vol. 10, no. 4, pp. 271-296, 1991. Available: 10.1287/mksc.10.4.271.

[15] W. Reinartz and V. Kumar, "On the profitability of long-life customers in a noncontractual setting: An empirical investigation and implications for marketing”, Journal of Marketing, vol. 64, no. 4, pp. 17-35, 2000. Available: 10.1509/jmkg.64.4.17.18077.

[16] A. Gupta, B. Su and Z. Walter, "An empirical study of consumer switching from traditional to electronic channels: A purchase-decision process perspective”, International Journal of Electronic Commerce, vol. 8, no. 3, pp. 131161, 2004. Available: 10.1080/10864415.2004.11044302.

[17] H. Ahmed, "Formulation of two-stage stochastic programming with fixed recourse", Britain International of Exact Sciences (BIoEx) Journal, vol. 1, no. 1, pp. 18-21, 2019. Available: 10.33258/bioex.v1i1.23. 
[18] T. Ibaraki and N. Katoh, Resource allocation problems, MIT Press, 1988.

[19] L. Hellemo, P. Barton and A. Tomasgard, "Decision-dependent probabilities in stochastic programs with recourse”, Computational Management Science, vol. 15, no. 3-4, pp. 369-395, 2018. Available: 10.1007/s10287018-0330-0.

[20] A. Shapiro, D. Dentcheva and A. Ruszczyński, Lectures on stochastic programming: modeling and theory. SIAM, 2014.

[21] E. Aromataris and A. Pearson, "The systematic review", American Journal of Nursing, vol. 114, no. 3, pp. 53-58, 2014. Available: 10.1097/01.naj.0000444496.24228.2c.

[22] B. Kitchenham, O. P. Brereton, D. Budgen, M. Turner, J. Bailey and S. Linkman, "Systematic literature reviews in software engineering - A systematic literature review”, Information and Software Technology, vol. 51, no. 1, pp. 7-15, 2009. Available: 10.1016/j.infsof.2008.09.009.

[23] B. Kitchenham, "Systematic reviews", in 10th International Symposium on Software Metrics, 2004. Proceedings. IEEE, 2004, pp. xii - xii.

[24] H. Li and Y. Yang, “Optimal keywords grouping in sponsored search advertising under uncertain environments", International Journal of Electronic Commerce, vol. 24, no. 1, pp. 107-129, 2020. Available: 10.1080/10864415.2019.1683704.

[25] X. Sun, S. Chung, T. Choi, J. Sheu and H. Ma, “Combating lead-time uncertainty in global supply chain's shipmentassignment: Is it wise to be risk-averse?”, Transportation Research Part B: Methodological, vol. 138, pp. 406-434, 2020. Available: $10.1016 /$ j.trb.2020.05.015.

[26] V. Tunuguntla, P. Basu, K. Rakshit and D. Ghosh, "Sponsored search advertising and dynamic pricing for perishable products under inventory-linked customer willingness to pay", European Journal of Operational Research, vol. 276, no. 1, pp. 119-132, 2019. Available: 10.1016/j.ejor.2018.12.026.

[27] S. Marković, M. Vujošević and D. Makajić-Nikolić, "An optimization-simulation approach to chance constraint programming", Information Technology And Control, vol. 47, no. 2, 2018. Available: 10.5755/j01.itc.47.2.18712.

[28] M. K. Mantrale and V. K. Kanuri, "Marketing optimization methods", in Handbook of Marketing Analytics. Edward Elgar Publishing, 2018.

[29] J. Sedina, "Multicriteria and robust extension of news-boy problem," 2018.

[30] C. Beltran-Royo, L. Escudero and H. Zhang, "Multiperiod multiproduct advertising budgeting: Stochastic optimization modeling”, Omega, vol. 59, pp. 26-39, 2016. Available: 10.1016/j.omega.2015.02.013.

[31] I. Rahaman and P. Hosein, "On the multi-stage influence maximization problem", in 2016 IEEE Latin American Conference on Computational Intelligence (LA-CCI). IEEE, 2016, pp. 1-6. [Accessed 25 May 2021].

[32] A. Legrain and P. Jaillet, "A stochastic algorithm for online bipartite resource allocation problems", Computers \& Operations Research, vol. 75, pp. 28-37, 2016. Available: 10.1016/j.cor.2016.05.004.

[33] A. Shapiro, "Stochastic programming approach to optimization under uncertainty", Mathematical Programming, vol. 112, no. 1, pp. 183-220, 2007. Available: 10.1007/s10107-006-0090-4. 